Illinois State University

ISU ReD: Research and eData

Theses and Dissertations

3-18-2015

\title{
Antecedents and Correlates of Work Engagement in Adolescents
}

Nichoals James Strong

Illinois State University, nick.strong@allstate.com

Follow this and additional works at: https://ir.library.illinoisstate.edu/etd

Part of the Psychology Commons

\section{Recommended Citation}

Strong, Nichoals James, "Antecedents and Correlates of Work Engagement in Adolescents" (2015).

Theses and Dissertations. 356.

https://ir.library.illinoisstate.edu/etd/356

This Thesis is brought to you for free and open access by ISU ReD: Research and eData. It has been accepted for inclusion in Theses and Dissertations by an authorized administrator of ISU ReD: Research and eData. For more information, please contact ISUReD@ilstu.edu. 


\title{
ANTECEDENTS AND CORRELATES OF WORK ENGAGEMENT IN ADOLESCENTS
}

\author{
Nicholas J. Strong
}

37 Pages

May 2015

An introduction to the experience of part-time work during adolescence is a key developmental and learning milestone during the lifespan. However, work engagement is an often overlooked construct during this time period as it relates to adolescent development. Specifically, this study examined the antecedents and correlates of work engagement. A sample of working adolescents included 97 participants from four high schools who completed an online survey. Work engagement, school engagement, w ork-school conflict, job type, job characteristics, hours w orked per week, and job satisfaction were measured using self-report questionnaires. Support was found for job satisfaction correlating with work engagement. Task significance and task identity were also found to be signific ant predictors work engagement. Support was not found for w ork-school conflict moderating the relationship between w ork and school engagement, work engagement differing by job type, and work hours predicting work engagement. 


\section{ANTECEDENTS AND CORRELATES OF WORK \\ ENGAGEMENT IN ADOLESCENTS}

NICHOLAS J. STRONG

A Thesis Submitted in Partial Fulfillment of the Requirements for the Degree of

MASTER OF SCIENCE

Department of Psychology

\section{ILLINOIS STATE UNIVERSITY}


(C) 2015 Nicholas J. Strong 


\section{ANTECEDENTS AND CORRELATES OF WORK \\ ENGAGEMENT IN ADOLESCENTS}

NICHOLAS J. STRONG

COMMITTEE MEMBERS:

Kimberly T. Schneider, Chair

John F. Binning 


\section{ACKNOWLEDGMENTS}

The writer wishes to thank, first and foremost, my current and former committee members, Kimberly Schneider, Patricia Jarvis, and John Binning. They introduced me to the love I have for Psychology. I would never be made it this far academically nor professionally without each of their support. Their coaching, guidance, and support not only pushed me through graduate school, but also helped set me up for my career as a professional. I'd like to specifically mention Kim again, who since my undergraduate days, has helped guide me where I'm at today. The academic and professional foundation each of these professors helped me build will leave me forever grateful. I would also like to thank the undergraduate assistants for their time and efforts that helped collect data for this study. Also, Neuqua Valley High School teacher Carol Grecu, who without her support in allowing us to use class time, I may have not garnered a large enough sample size to finish this study. Finally, I would like to thank my family and friends for their continued support, particularly my mom. Her unabashed support for me since I came into this w orld leaves me forever indebted.

N. J.S. 


\section{CONTENTS}

Page

ACKNOWLEDGMENTS

CONTENTS

TABLES $\quad$ iii

FIGURES

CHAPTER

I. REVIEW OF LITERATURE 1

Adolescent Work Experiences 2

Work-School Relationship, Job Type, and Job Characteristics 3

Work Value Development $\quad 8$

Employee Engagement 12

II. CURRENT STUDY 16

$\begin{array}{llr}\text { III. } & \text { METHODS } & 18\end{array}$

$\begin{array}{lr}\text { Participants } & 18\end{array}$

$\begin{array}{ll}\text { Procedure } & 18\end{array}$

Utrecht Engagement Scales (School and Work) 19

Job Diagnostics Survey 20

Job Descriptive Index $\quad 20$

Work-School Conflict 20

IV. RESULTS 22

V. DISCUSSION 25

$\begin{array}{lr}\text { Limitations and Future Directions } & 29\end{array}$

REFERENCES 34 


\section{TABLES}

$\begin{array}{ll}\text { Table } & \text { Page }\end{array}$

1. Count \& Percent of Age, Gender, Job Categories, and Average Hours Worked per Week

2. Means, Standard Deviations, and Correlations Between Measures 32

3. Job Type and Work Engagement Score 33 


\section{FIGURES}

$\begin{array}{ll}\text { Figure } & \text { Page }\end{array}$

1. Dimensions of work quality (z-scores) in 12th grade by job type. 7

2. Job Characteristics Model relating job dimensions, the critical psychological states, and on-the-job outcomes $\quad 8$

3. Framew ork for understanding the elements of employee engagement 13

4. Scatterplot comparing average hours worked per week to w ork engagement 


\section{CHAPTER I}

\section{REVIEW OF LITERATURE}

The introduction to the experience of part-time work during adolescence is a key

developmental and learning milestone during the lifespan. As Erikson (1968) explained, experimenting with vocational roles and vocational discovery is essential to identity formation in adolescence. The work environment provides a context where adolescents can start to define themselves, develop social competences, and increase their social roles (Mortimer, ZimmerGembeck, Holmes \& Shanahan, 2002). Working during high school years has become common for a vast majority of high school students in today's age where over $75 \%$ of high school students have a paid job at some point by their senior year of high school (Staff, Messersmith, \& Schulenberg, 2009). Employment during adolescence can also offer networking opportunities with access to information; adolescents may learn information about themselves from these initial w orking experiences (e.g., levels of responsibility, problem-solving abilities). Levine and Hoffner (2006) stated that exploration during adolescence includes choosing vocations based on information gathered about oneself and one's environment (Bluestein, 1997; Grotevant, 1992). This has been studied both practic ally (i.e., associated outcomes) and theoretically (i.e., identity formation, transition into adulthood).

Most of the literature on adolescent work focuses on the experience in relation to adolescents' academic outcomes (for a review, see Zimmer-Gembeck \& Mortimer, 2006). Many negative outcomes have been observed regarding work intensity (i.e., differences between w orking under and over twenty hours per week) in adolescents during high school, including lower GPA and increased school absences (Barling, Rogers, \& Kelloway, 1995; Schoenhals, 
Tienda, \& Schneider, 1998). However, very little research has been conducted on contextual variables influencing adolescent job satisfaction or engagement. No studies have directly measured employee engagement in adolescence and its antecedents and/or correlates. The current study will assess adolescents' work engagement and links between engagement and job attitudes.

Engagement can be defined as a positive and fulfilling school- or work-related state of mind that is characterized by vigor, dedic ation and absorption (Schaufeli, Salanova, GonzalezRoma, \& Bakker, 2002). The following sections review the construct of employee engagement and what is known about the construct based on adult samples (Macey \& Schneider, 2008), as well as the adolescent w ork literature with a focus on adolesc ents' perceptions of work (Levine \& Hoffner, 2006; Wirtz \& Charner, 1988), voc ational development (Erikson, 1968; ZimmerGembeck \& Mortimer, 2006), work-school conflict (Mortimer, Finch, Ryu, \& Shanahan, 1996; Shanahan \& Floherty, 2001; Zimmer-Gembeck \& Mortimer, 2006), and quality of the work experience (Mortimer et al., 1996; Stern, Stone, Hopkins, McMillion, 1990).

\section{Adolescent Work Experiences}

According to the Bureau of Labor Statistics (December 2013), about 16\% of 16-17 year olds and $26 \%$ of $16-19$ year olds were employed at the time of their survey in 2013 . According to the Youth Development Study (Mortimer, 2003), 58\% of male adolescents and 70\% of female adolesc ents are employed at some point by their senior year of high school, while over $90 \%$ of employed adolescents begin working during their sophomore year. How ever, adolescents may lack the experience adults normally have when making occupational decisions. Levine and Hoffner (2006) studied five sources of information (e.g., parents, educational institution, parttime employment, friends, and mass media) that provide anticipatory socialization, or knowledge gained about the work experience during early childhood until young adults enter the work force full-time. Levine and Hoffner administered a self-report questionnaire focused on what participants learned about work from each source to 64 high school students between the ages of 
14 and 18 (around 75\% held one or more part-time jobs). Responses to the open-ended items were then categorized into 4 groups: general requirements about a job, positive aspects of work, negative aspects of work, and advice or information about w ork/jobs.

Overall, parents and part-time work itself communicated the most information about w ork to the adolescent respondents. Levine and Hoffner (2006) found that parents, the educational institution, and part-time employment were the main sources of knowledge about the requirements of performing a job. Parents provided the most advice about jobs and careers. How ever, parents along with friends conveyed more negative than positive information about work such as "sometimes the boss gives you a hard time" and "my friends told me that working a job is not fun." It is interesting to note that data were collected in a relatively economic ally stable period in the U.S. (2000). However, with the recent state of the economy exhibiting periods of economic decline and uncertainty, it is possible that negative aspects related to work are increasingly communic ated to adolescents by all sources. This may have an effect on how engaged with work the current cohort of adolescents is because they do not have much prior work experience with which to evaluate and interpret the vocational world. Although Levine and Hoffner's (2006) study was limited both in sample size (small), and diversity (mostly Caucasian, middle-upper class socioeconomic background), it is a good start in illustrating where the adolescent gains know ledge about the world of work.

\section{Work-School Relationship, Job Type and Job Characteristics}

Wirtz and Charner (1988) studied how academic performance relates to adolescents' perceived approval from parents and school employees (e.g., teachers, school officials) regarding w ork. Their nation-wide sample consisted of 457 adolescent employees working at fast-food establishments and planning to attend college ( $41 \%$ male, $59 \%$ female; $86 \%$ Caucasian).

Participants were separated into three different academic categories: A-average, B-average, and $\mathrm{C}$-average. The participants were asked to rate perceived approval of adolescents working from parents, teachers, and other school officials. The authors found that teachers and other school 
officials generally were perceived as disapproving of work for adolescents. Parents were perceived as generally approving of work, regardless of adolescents' work intensity (hours per week). Only for $\mathrm{C}$-average students was there a significant negative relationship between work intensity and perceived level of approval by school personnel. A- and B-average students had a positive but non-significant relationship between w ork intensity and perceived level of approval by school personnel. The Levine and Hoffer (2006) and Wirtz and Charner (1988) studies showed that although adolescents heard about negative aspects of work more frequently than positive work aspects from their parents (Levine \& Hoffner, 2006); they generally perceived parents as approving of work (Wirtz \& Charner, 1988). However, this should be interpreted with caution. One possible confounding variable was the state of the economy during each of these studies, which were conducted twelve years apart (Levine \& Hoffner collected their data in 2000).

Zimmer-Gembeck and Mortimer (2006) discussed the negative school outcomes presumed to result from adolescents working intense hours (i.e., over 20 hours per week) that are often reported, such as decreased engagement in school (e.g., taking easier classes, leaving school early), less time spent on homew ork, and poorer school attendance (e.g., Barling, Rogers, \& Kelloway, 1995; Marsh \& Kleitman, 2005; Schoenhals, Tienda, \& Schneider, 1998). Other studies have also supported similar findings of adolescents working over 20 hours per week having lower GPAs, substance abuse and school misconduct (Uggen \& Wakefield, 2008), as well as higher high school drop-out rates (Lee \& Staff 2007).

Zimmer-Gembeck and Mortimer posed an important question in their review of the literature - how can adolescents be incorporated into the world of adult w ork without being distracted from school and personal development? Erikson would argue that the w ork experience is part of personal development, but it is important to note that occupational identity is only a part of the development process, not the entirety or even a majority during adolescence. ZimmerGembeck and Mortimer (2006) highlighted the notion that the work and school domains should 
not be seen as competitive, but as complementary (see Stone \& Mortimer, 1998; Hamilton, 1990) to one another when work is moderate (approximately 10 hours per week). Multiple studies (Greenberg \& Steinberg, 1986; Mihalic \& Elliot, 1997; Mortimer et al., 1996; Schill, McCartin, \& Meyer, 1985; Steinberg \& Cauffman, 1995) have shown that when students w ork few (i.e., close to zero hours) or intense w ork hours (i.e., more than 20 hours per week) they have a tendency to have lower academic outcomes compared to adolescents who work a moderate number of hours (around 10 hours per week). These studies show a trend in literature that points at w ork being beneficial when done in moderation. This curvilinear relationship between w ork intensity (hours per week) and academic achievement may also be observed in school engagement and w ork hours. Shanahan and Flaherty (2001) also found that students who were active workers (work intensity was not measured) did not differ from non-workers in the amount of time spent on homew ork among grade 9, 10, and 12 participants. Among grade 11 participants, active workers actually spent more time on homew ork than non-workers. Thus, there may be some positive overlap at a certain age between work and school in that positive w ork ethic developed on the job may spill over into positive school habits, such as time spent on homew ork.

The type of data many of these researchers have relied upon is important to note because most researchers have focused on the quantitative aspects of adolescent work as a proxy for the quality of the adolescent work experience (e.g., Shanahan et al., 1996; Stern \& Nakata, 1989; Stern et al., 1990). An analogy could be given to measuring academic outcomes if only total hours in schoolwere measured and not the quality of instruction or program. This also paints a false comparis on that work and school always conflict with no supplemental or complimentary learnings that can be applied across domains. That will likely depend on the quality and type of the job the adolescent holds. Zimmer-Gembeck \& Mortimer concluded that many studies on w ork quality receive little replic ation or theoretical guidance relative to specific outcomes (such as work and school engagement). It is this researcher's notion that more research is needed to 
examine contextual factors (e.g., quality/type of work) in order to understand the experience of w ork during adolescence.

In a review of literature by Staff and Schulenberg (2010) on adolescent work experiences, the authors found that quality of the work experience and type of job had significant implications for school and w ork conflict (e.g., report fewer hours on homework, lower grades, graduation rates), as well as adolescents' perceptions of work. Figure 1 shows the relationship between job quality (stress and tension; education, family or social interference, makes good use of skills, learn new skills, teenage coworkers, and career-relatedness) and job type (informal, fast food, restaurant, farm or agriculture, retail, office or clerical, other). Staff and Schulenberg (2010) found that low skill/quality jobs such as fast food workers and retail were the most stressful, interfered more with students' education, family and friends, and were less career-related compared to other job types. Conversely, jobs of the office or clerical type were the opposite, with more opportunity for the adolescent to learn and apply new skills and relate to a future career. Fast food jobs were also shown to use the least amount of job skills. It may be that low skill/quality jobs are more stressful because they do not align with future career plans, and often consist of repetitive and mundane tasks. This increased stress may lead to less engagement and energy devoted towards schoolw ork. Staff and Schulenberg (2010) concluded that work does not simply interfere with school but certain types of work (e.g., quality, makes good use of skills) and number of hours worked per week (e.g., less than 20 hours) can change the nature of this relationship. This relationship should further be explored with similar constructs such as work engagement and job type. Job type could even be further broken dow $n$ to the job skills required and job characteristic s that encompass the work tasks involved. 


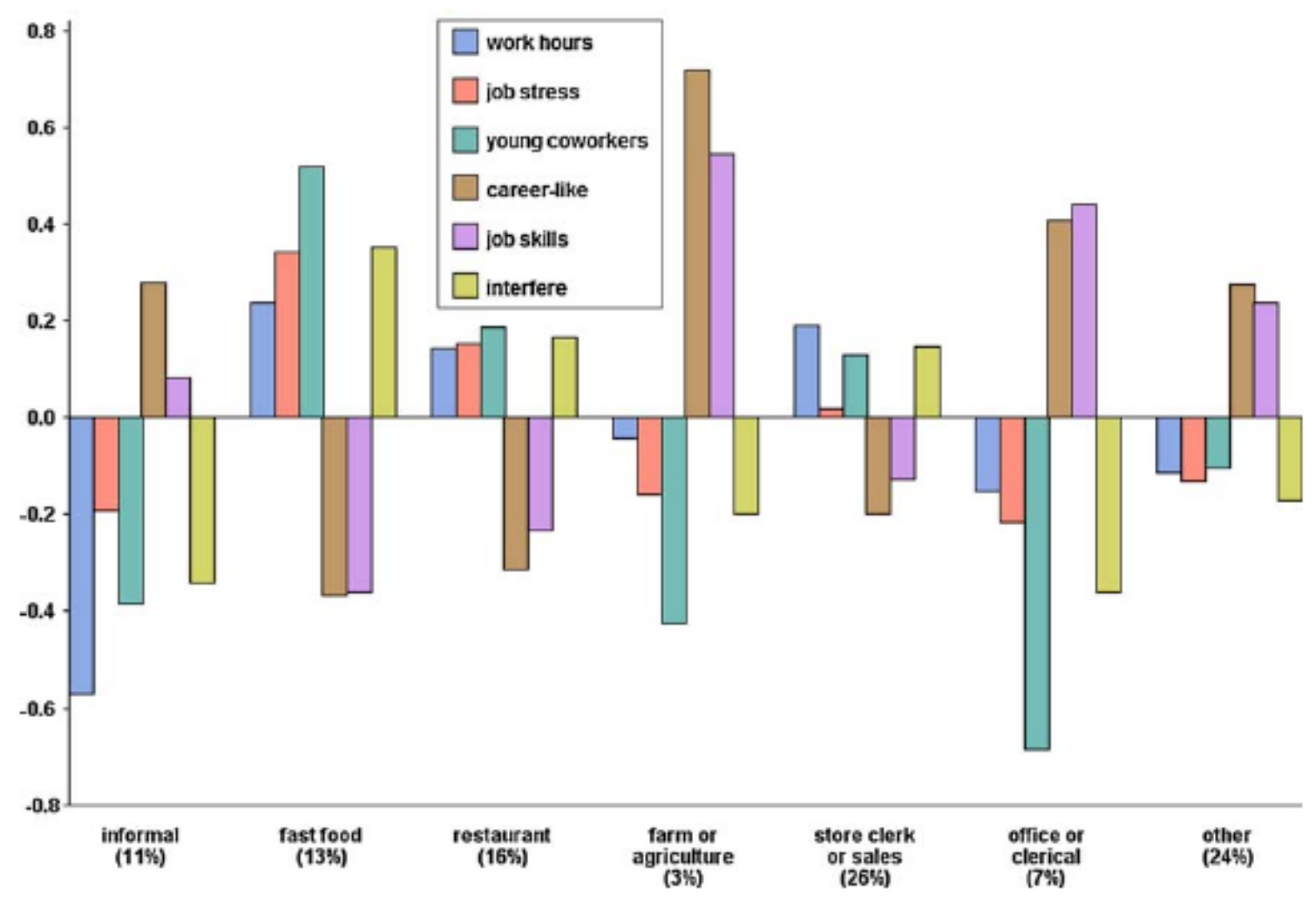

Figure 1. Dimensions of work quality (z-scores) in $12^{\text {th }}$ grade by job type.

Job characteristic s were further studied by Loher, Noe, Moeller, and Fitzgerald (1985) in a comprehensive review via a meta-analysis of the relationship between job characteristics and job satisfaction. Job characteristic s were defined as consisting of skill variety, task identity, task signific ance, autonomy, and feedback. Loher et al. (1985) use Hackman and Oldham's (1975) Job Characteristics Model as presented in Figure 2 This model highlights their definition of job characteristic s based on five distinct areas: skill variety, task identity, task signific ance, autonomy, and feedback. The authors predicted that an employee's growth need strength (GNS; job incumbents' need for personal development and growth through a job) would moderate job characteristics and outcomes. This may be highly important for adolescents as this is a time when they are developing their identity, both personally and vocationally. Loher et al. (1985) only included studies that used Hackman and Oldham's Job Diagnostics Survey (JDS) or measures 
similar to the JDS. In total, 28 studies were included in the meta-analysis. They found signific ant correlations between the Job Characteristics Index (comprised of the mean score from the five job characteristics) and job satisfaction. These results show that job characteristics do significantly impact an employee's job satisfaction. Also, GNS was found to be a significant moderator between job characteristics and job satisfaction. A correlation between job characteristics and job satisfaction was significantly higher for participants who scored higher on GNS as opposed to participants who scored lower on GNS. This study demonstrated that job characteristics play an important role in an employee's job satisfaction. This finding may extend to an employee's work engagement as satisfaction and engagement have overlapping characteristics.

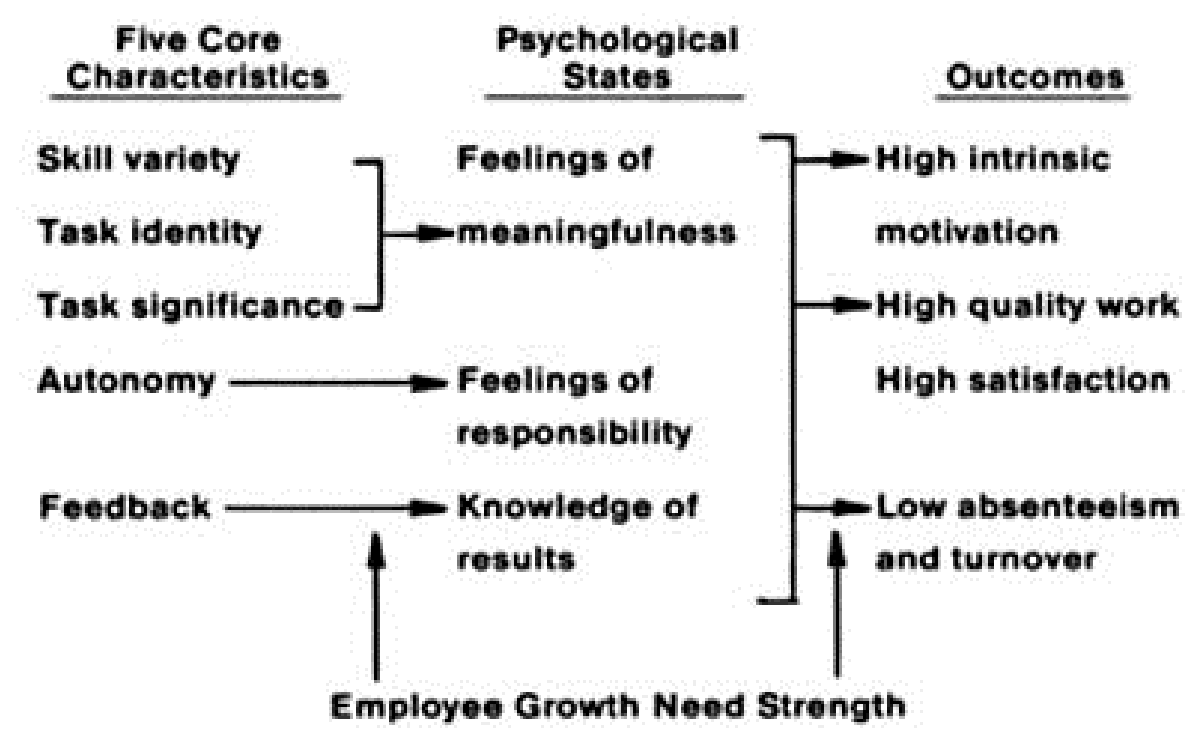

Figure 2. Job Characteristics Model relating job dimensions, the critical psychological states, and on-the-job outcomes

\section{Work Value Development}

Erikson's (1968) framework of identity formation (specifically occupational identity) and Bronfenbrenner's (1979) view that ecological systems in life must be juxtaposed in order to understand any single influence on human development, guided Mortimer et al.'s (1996) research on part-time work in adolescence in relation to occupational value formation. Mortimer et al. 
(1996) conducted a 4-year longitudinal study of high-school adolescents and focused on important features of their current work in relation to their perception of job hunting when they started applying for full-time jobs post-high school. Their sample included roughly 930 participants, who completed questionnaires annually for four years (freshman to senior year of high school). The questionnaire asked, "In the future, how important do you think each of the following will be to you when you are looking for a full-time job?" Participants answered on a 4point Likert-type scale ("not important" to "very important"). Extrinsic features such as income, advancement opportunity, security, and prestige were examined, as well as intrinsic features such as use of skills and abilities, opportunity to learn, autonomy, responsibility, w orking with others, and being helpful. The questionnaire also asked how their current jobs helped develop job skills, helpfulness to others, and focused on evaluations of pay and stressors.

Mortimer et al. (1996) tested three competing models in their relation to w ork value formation. The first focused on a Competence model —in w orking during adolescence, teens develop attitudes, values, habits, and know ledge so that they will be better employees as adults; the second was a Cynicism model — because the jobs that most teenagers are able to get require relatively low-level skills, adolescents become cynical about work and work only for extrinsic benefits; the third was No influence on work on values model and proposed that because these jobs are only seen as temporary and adolescents will often get an unrelated job after school is completed, the work experience would have no effect on adolescents. The goal of the study was to determine if these models generalized to adolescents.

The findings supported the Competence model and also indic ated that work environment, as well as intrinsic and extrinsic values, influence what occupational values are developed. An important note is that work environment is typically a situational factor, while values are individual factors, showing that occupational values are influenced by both internal and external factors. Adolescents are forming their vocational identities from different cues. How ever, the authors did not find support for the latter two models (cynicism and no influence models). The 
study provides some support for the notion that as adolescents mature, their values, work experiences and individual differences become more similar to adults as they are at the start of their transition to adulthood.

Stern et al. (1990) also measured cynicism along with motivation, but from a different perspective than Mortimer et al. (1996). Stern et al. (1990) defined cynicism as the perception that companies do not care about employees and jobs are not worthy of workers' commitment. Motivation was defined as commitment to high quality work and performing better than the least effort required. Specific ally, Stern et al. (1990) examined whether there were associations between characteristics of students' jobs and their general attitudes tow ard work. Participants were given an annual survey (for five years) that measured characteristic s of students' current jobs, such as substantive complexity (Kohn \& Schooler, 1982), which is comprised of the job's cognitive complexity required to perform central tasks, the physical challenge involved, and the opportunity for the adolescent to develop work-related social competence. Students' orientations towards w ork (e.g., motivation, cynicism), autonomy, and perceived work-school conflict were also studied. The sample consisted of two geographically different groups: Group 1 consisted of 350 students at two Midwestern city specialized high schools (business magnet school, trade and technical school); and Group 2 consisted of 339 students at four public high schools in a southern town. Group 1 was more diverse (58\% Caucasian; $42 \%$ minority) than Group 2, which was largely Caucasian (96\%).

Stern et al. (1990) found that holding all other demographic variables constant, gender, age, and geographic location were the most significant demographic predictors of motivation and cynicism. More specifically, seniors and female participants expressed the strongest motivation and least cynicism. This may show that different types of adolescents have different perceptions of work. Group 2 (public high school students) scored significantly higher on w ork motivation than Group 1. The strongest job characteristic predictors of attitudes were perceived work-school conflict (negatively related), physical challenge (positively related), opportunity to learn new 
things (positively related), and use of skills and abilities (positively related). This may indicate that if a respondent thinks the job will interfere with school, they may be more inclined to have negative attitudes tow ard their job. However, stimulating job characteristics such as physically challenging work, learning new things, and using skills and abilities may lead to a more positive outlook on work. It is important to note that maturation or continued work experience may explain the more positive attitudes tow ard work in seniors. Stern et al (1990) conducted one of the few studies that examined the quality of the work experience rather than the quantity of hours w orked. It may be that mental and physical challenge in adolescent employment motivates them to do better w ork, which may affect employee engagement, to be discussed in the next section.

The Stern et al. (1990) study was specific to working adolescents and it may indic ate that employers are selecting highly motivated adolescents. Therefore, the sample may include limitations of range restriction which could inflate the motivation scores. The types of school included in the study are also important to evaluate as Group 1 consisted of rare "specialty" schools and Group 2 was comprised of southern schools in a rural area. However, this study does shed light on different areas in adolescents' life that may shape their attitudes tow ard work.

The relationship of the type of work an adolescent is doing to his or her future life plans (e.g., career as an adult) may also impact how engaged he or she may be. Luyckx, Duriez, Klimstra, \& De Witte (2010) discussed how young adult employees make and evaluate identityrelated decisions about their future that may be important for their perceptions of their jobs. This discussion is rooted in research by Schwartz, Cote, \& Arnett (2005) who found that if an individual has thought about what they want to do as a career choice when they are an adult, they may experience more engagement and less burnout by being able to connect the current job to the future. On the contrary, if the job the individual holds is low-skill and unrelated to his or her future career vision, he or she may exhibit less engagement in the job and more burnout (Schwartz et al., 2005). This could also apply to adolescents thinking about their career choices. If they are in a low skilled job, this may lead to them be less engaged. 
Although gaps exist in research between the relationship between w ork engagement and school engagement, there has been some interesting w ork on the relationship between career development, school engagement and academic motivation beliefs. Although work engagement w as not studied, Brogan (2010) is one of the few researchers that examined career development and school engagement during adolescence (middle school ages 11-16). Brogan defined career progression and development as multi-dimensional, made up of Curiosity/Exploration, Information, Locus of Control, Planning, Interest, Key Figures, and Time and Self-Concept. Brogan found that middle school students who reported higher levels of career progression also reported higher levels of engagement and academic motivational beliefs. This lends support to the notion that the further along an adolescent is with envisioning his or her future career that he or she may relate this to engagement in school. When adolescents begin working during their teenage years, the quality of the job and link with their future career aspirations may play a role in school engagement and work engagement. Related findings were also found by Kenny, Blustein, Haase, Jackson, \& Perry (2006) whereas the relationship between school engagement and career development (career planfulness and career expectations) were examined via self-report questionnaires. Bluestein et al. (2006) found that increases in school engagement were as sociated with higher levels of career development (career planfulness and career expectations) among $9^{\text {th }}$ graders, thus showing that this trend may continue into high school.

\section{Employee Engagement}

Employee engagement is a concept that has been continually gaining attention in academia and organizational practice for the past couple of decades. The construct has been discussed in academic circles where researchers have debated its definition and measurement. Macey \& Schneider (2008) reviewed the current literature on employee engagement and separated the definition of engagement into three different types: trait (i.e., a disposition similar to positive affect); state (i.e., a psychological state such as involvement, commitment, attachment, and mood) and behavior (i.e., observable behaviors such as prosocial and extra-role behaviors). 
Their theoretic al model predicts that trait engagement is the underlying construct that will generally lead to state engagement, which will then lead to behavioral engagement.

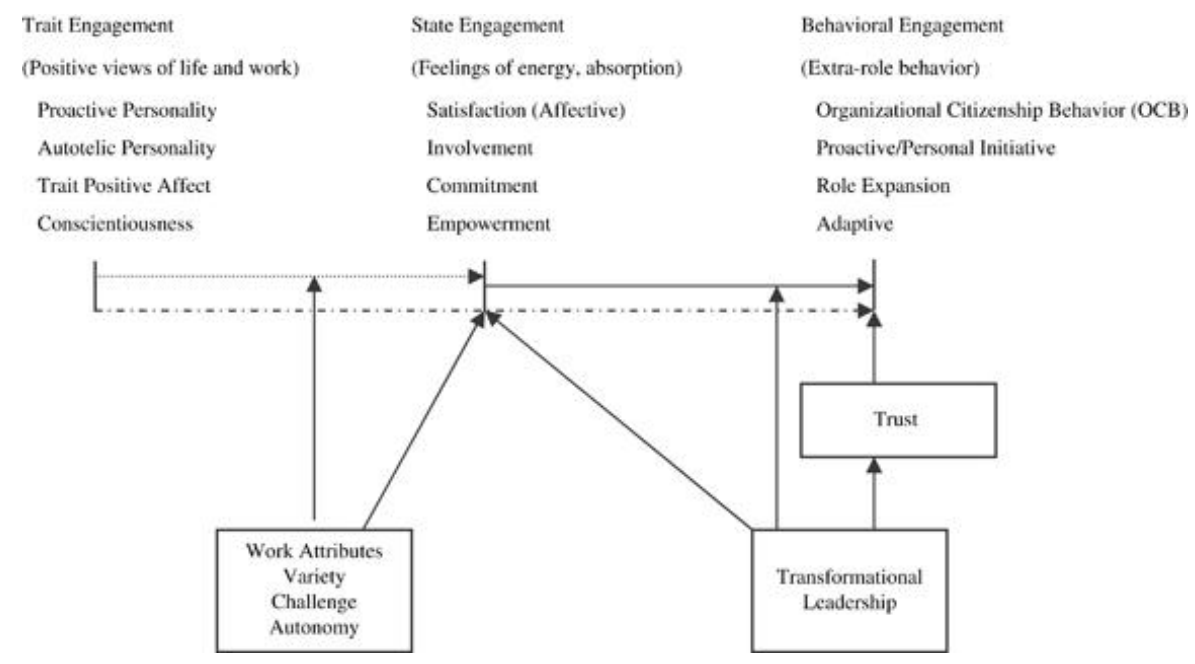

Figure 3. Framework for understanding the elements of employee engagement.

Macey and Schneider's (2008) paper on the concept of employee engagement was important because instead of delineating which definition of engagement is correct, the authors specified how they interact. In other words, the authors presented the notion that employee engagement can be view ed from different perspectives. Macey and Schneider further detailed their model by showing the direct and indirect relationships between the different types of engagement and important moderators. Work attributes, variety, challenge, and autonomy will indirectly impact the relationship between trait and state engagement, whereas they will have a direct effect on state engagement. Transformational leadership, defined as a leader who inspires, intellectually stimulates, and is individually considerate of others (Bass, 1999), can directly affect state engagement and has an indirect effect (via trust) on behavioral engagement, as well as the link between state and behavioral engagement.

Macey and Schneider showed that engagement has been compared to similar job-related constructs such as satisfaction (see Burke, 2005; Harter, Schmidt, \& Hayes, 2002; Towers-Perrin, 2003), commitment (Wellins \& Concelman, 2005), job involvement (see Brown, 1996; Harter et al., 2002), and positive affectivity (Fleming, Coffman, \& Harter, 2005). Although some 
researchers have argued that engagement is merely old wine in a new bottle being too similar to constructs such as satisfaction (Newman \& Harrison, 2008), Macey and Schneider stated that although engagement retains aspects of these concepts, it is not a simple addition of any of them that makes up engagement. The authors argue engagement has more distinct characteristics such as affect and feelings of energy, whereas it does not include the previous concepts when they are connoted with satiation and contentment.

Harter et al. (2002) created an engagement measure (The Gallup Work Place Audit) and defined it specifically as a satisfaction-engagement scale. Harter et al. (2002) defined engagement as "the individual's involvement and satisfaction with—as well as enthusiasm forwork” (p.269). Burke et al. (2005) measured work engagement as a direct facet of satisfaction with some aspect of an organization (e.g., manager and/or job satisfaction). Although engagement is related to satisfaction, the two are not the same concepts according to Macey and Schneider (2008). Employee engagement extends job satisfaction to another level and involves not only simple satisfaction, but passion, commitment, personal investment, goal setting, and effort to help an organization succeed in meeting these goals(Erickson, 2005). Satisfaction is merely one aspect of engagement.

Schaufeli, Salanova, Gonzalez-Roma, and Bakker (2002, p. 74) defined engagement as "a positive, fulfilling work-related state of mind that is characterized by vigor, dedic ation and absorption.” From this, Schaufeli, Bakker, \& Salanova (2006) designed the revised Utrecht Engagement Scale based on this definition of engagement. Schaufeli et al. (2006) incorporated vigor (high energy levels and mental resilience towards work), dedic ation (being strongly involved in work that has meaning and provides challenge), and absorption (being engrossed fully in work) as the three sub-scales that comprise engagement. However, they concluded that the scale fits the data reasonable well as a one-factor model to measure overall engagement.

An important note is that no studies have been conducted on adolescent work engagement even as work engagement becomes a well-utilized construct in both academic and 
professional settings. As previously stated, the realm of adult work and adolescent work are different, as the job needs and perhaps job experiences will differ greatly for between both groups (Zimmer-Gembeck \& Mortimer, 2006). Job satisfaction has also been overlooked to a large extent in the adolescent work literature, in relation to other concepts measured. Future research should begin to emphasize adolescent work engagement to compare similarities and differences to adult work engagement. Because adolescence is also an important time for identity formation it may be related to key outcomes of adolescents' career exploration and job experiences as they get older. In addition, most literature has only examined the quantitative aspects of adolescent w ork (e.g., work intensity) rather than qualitative aspects including w ork context variables. Although the former is important, it is just as important to look at the quality of the work experience, which may be reflected in assessments of job engagement. 


\section{CHAPTER II}

\section{CURRENT STUDY}

The focus of the current study is to measure work engagement in adolescents and the potential antecedents, correlates, and moderators that impact it. Work engagement during adolescence is an unmeasured construct yet may be a very important one as identity formation plays a significant role during this time. Adolescence is also a time in life where identity formation plays a significant role in developing the adult an individual will become and work and school are important factors during this time. The relationship between work and school engagement will be studied to see how the two may interact, with perceived w ork-school conflict being examined as a moderating variable. Although the central aim of this study is to measure engagement, and not satisfaction, it is important to note the two can overlap and their relationship should be studied. Job characteristics and job type may also play an important role with how engaged the adolescent is with his or her work. Specific ally, job types requiring less skill such as fast food or retail may produce less engagement in their workers (Staff \& Schulenberg, 2010). Job characteristic s (skill variety, task identity, task significance, autonomy, and feedback) have also been shown to be related to job satisfaction (Loher et al., 1985). Since job satisfaction and engagement have been shown to be related (Macey \& Schneider, 2008), this relationship may exist between work engagement and job characteristics. Specifically, it may be that job characteristics such as task significance or task identity will be related to more engaged workers (compared to other job characteristics) given the importance the adolescent may place on learning these skills.

Hypotheses for the current study are as follow s: 
Hypothesis 1: Work-school conflict will moderate the relationship between w ork engagement and school engagement among a sample of adolescent employees. Specifically, for those with high work-school conflict there should be a negative relationship between w ork and school engagement; but for those with low w ork-school conflict there should be a positive relationship between work and school engagement.

Hypothesis 2: Job satisfaction will be positively correlated with work engagement among a sample of adolescent employees.

Hypothesis 3: Job characteristic s (autonomy, feedback, skill variety, task signific ance, and task identity) will be positively related to work engagement among a sample of adolescent employees. Specifically, task significance and task identity will be the strongest predictors of engagement.

Hypothesis 4: Work engagement will differ based on participants' job type (e.g., clerical, managerial, physical labor, customer service, retail/sales position, childcare, fast food, restaurant work). Specifically, participants with fast food jobs (require less skill) will be less engaged in their job compared to other job types.

Hypothesis 5: Hours worked per week will have a curvilinear relationship (inverted Ushaped) with work engagement. 


\section{CHAPTER III}

\section{METHODS}

\section{Participants}

A total of 97 participants were included in the current study ranging between the ages of

15-17, with a vast majority (95\%) being 17 . The participants attended the following four schools: Neuqua Valley High School(62\%), Bloomington High School(22\%), Tri-Valley High School (12\%), and University High School (4\%). The participants were $66 \%$ female and $44 \%$ male. Participants included in the study were required to be working at least 8 -hours per week. The mean hours worked per week was 16.76 hours with a standard deviation of 6.15 . All participants were required to obtain parental permission and to give their own assent. Permission to conduct the study was also obtained from the school administrators. Considering all types of analyses to be conducted and using Cohen's Power-Effect Size table, a medium effect size at power of .80 will require at most 85 participants at an alpha level of .05 (Cohen, 1988). Thus, a sample size of 85 or greater should satisfy Cohen's recommended sample size.

\section{Procedure}

In three of the school (University, Bloomington, Tri-Valley), participants were made aware of the study by an information table that was setup in the hallway, an announcement during lunchtime, or an announcement during gym class. For Neuqua Valley High School, participants were given class time to complete the survey. Participants who were interested in completing the questionnaire were provided a permission slip to be read and signed by their parents. When participants returned to the researchers a signed parental/guardian permission and gave their own 
assent, they were provided the link for the online survey. All students between the grades of 9-12 and ages 15-17 were invited to participate, with the only other requirement being the participant had a job of at least 8 hour per week. For three of the schools (University, Bloomington, and TriValley), the first class at each school to return the most signed permission letters was awarded a pizza party by the research team and with approval by their teacher.

The questionnaire was online and consisted of up to 262 items, depending on how the participant answered certain questions. The questionnaires additional items were around sexual harassment that were not utilized in this study. The first screen of the survey informed participants the study was going to ask them questions about their w ork experiences, that results were confidential and anonymous, and provided contact information for any and indicated that if they chose to continue they were giving assent to be in the study and that they may discontinue it at any time without penalty. Data were password-protected via an online survey provider as well as password protected on an SPSS file maintained by the co-principal investigator. Participants were asked to provide demographic information such as age, gender, and ethnicity, as well as information about their parents and family (parental education level and occupation, type of community). Job type was measured by asking the participants to indicate his or her job type (clerical, managerial, physical labor, customer service, retail/sales position, childcare, fast food, restaurant work-not fast food, other). Additionally the following scales were included:

\section{Utrecht Engagement Scales (School and Work)}

School and Work Engagement was measured with 9-item Utrecht Work Engagement Scale and the Utrecht Work Engagement Scale-Student Version (UWES-9; Schaufeli \& Bakker, 2003). Sample items in the UWES-9 include, "When I get up in the morning, I feel like going to class/my job", "I am proud of my studies/my job", "My job/studies inspire me." Both versions of the UWES-9 use a 7 point frequency response scale ranging from "almost never" to "always". 
Cronbach's alpha for the Utrecht Work Engagement Scale and School Engagement Scale were .93 and .90 , respectively.

\section{Job Diagnostics Survey}

The Job Diagnostic Survey (JDS; Hackman \& Oldham, 1975; 15 items) was used to measure job characteristics. Adolescent workers were asked to rate their jobs on the degree to which they allow autonomy, give feedback, offer skill variety and task significance, and allow task identity on scale ranging from 1 (very inaccurate) to 7 (very accurate). Sample items include the following: "The job requires me to use a number of complex or high-level skills." "The job is quite simple and repetitive." Reliability coefficients of .88 for autonomy, .89 for feedback, .88 for skill variety, .95 for task significance, and .82 for task identity were obtained in previous research. An alpha of .72 was obtained for the overall measure (Hackman, 1980). Thus, all reliability estimates were within acceptable limits.

\section{Job Descriptive Index}

Job satisfaction was assessed using the Satisfaction with Work (18 items). Data was also collected for Satisfaction with Cow orkers (18 items), and Supervision (18 items) subscales of the Job Descriptive Index (JDI; Smith, Kendall, \& Hulin, 1969 as revised by Roznow ski, 1989) for exploratory analyses. The JDI asks respondents to indicate to what extent a series of adjectives (e.g., challenging, important) describes their work in general, cow orkers, and supervision. All three subscales use a 3-point scale consisting of, “yes", "?”, and "no." Reliability coefficients of .87 for satisfaction with w ork, .90 for satisfaction with coworkers, and .91 for satisfaction with supervision have been reported (Roznowski, 1989).

\section{Work-School Conflict}

Work-school conflict was measured by the Work-School Conflict scale (WSC; Markel \& Frone, 1998). The four-item scale measures how individual's school and work interfere with one another. The Work-School Conflict scale includes four items including, "Because of my job, I go to school tired", My job responsibilities interfere with my school work", "I spend less time 
studying and doing homework because of my job", "My job takes up time that I would rather spend at school or on school work", and "At school, I spend a lot of time thinking about my job." The four items were averaged to form a composite score for the WSC variable. Coefficient alpha for the 4-item scale was .86. 


\section{CHAPTER IV}

\section{RESULTS}

Hypothesis 1 predicted that work-school conflict would moderate the relationship betw een work engagement and school engagement. Specific ally, for those with high work-school conflict there should be a negative relationship between work and school engagement; for those with low w ork-school conflict there should be a positive relationship between work and school engagement. A hierarchical regression was conducted to test this relationship. The variables were centered to avoid multi-collinearity. At step 1 of the analysis, school engagement and workschool conflict were entered into the regression equation and were positively signific antly related to work engagement, $F(2,86)=10.59, p<.001$. The adjusted $\mathrm{R}^{2}$ for the equation was .18 indicating approximately $18 \%$ of the variance of work engagement could be accounted for by school engagement and w ork-school conflict. In Step 2, the centered interaction between workschool conflict and school engagement w as entered into the equation and did not signific antly change the $\left.\mathrm{R}^{2}, F(1,85)=6.98, \mathrm{p}=.909\right)$. Hypothesis 1 was not supported.

Hypothesis 2 predicted that job satisfaction would be positively correlated with work engagement among a sample of adolescent employees. For correlational analyses, a one-tailed test at the .01 signific ance level was used to control for Type 1 error. As expected, the correlation between job satisfaction and w ork engagement was statistically signific ant. The correlation statistic for job satisfaction and work engagement was $r(78)=.64, p<.001$. Exploratory analyses were also conducted for the correlations between supervisor satisfaction and work engagement, and cow orker satisfaction and work engagement. Both of these correlations were 
statistically signific ant with supervisor satisfaction and work engagement, $r(72)=.38, p<.001$, and cow orker satisfaction and work engagement, $r(81)=.29, p=.004$.

Hypothesis 3 predicted that job characteristics (autonomy, feedback, skill variety, task signific ance, and task identity) would be positively related to w ork engagement among a sample of adolescents. Specifically, task significance and task identity would be the strongest predictors of work engagement. A multiple regression analysis was used to test the signific ance. As expected, job characteristics explained a significant portion of the variance in w ork engagement, $R^{2}=.50, F(5,83)=16.36, p<.001$. Further, task signific ance and task identity were the only two significant predictors of work engagement. Task signific ance signific antly predicted work engagement, $\beta=.51, t(83)=3.53, p<.001$. Task identity signific antly predicted work engagement, $\beta=.35, t(83)=2.02, p=.05$. Hypothesis $3 \mathrm{w}$ as supported.

Hypothesis 4 predicted that work engagement would differ based on participants' job type (e.g., clerical, physical labor, customer service, retail/sales position, childcare, fast food, restaurant work, other). Refer to Table 3 for Work Engagement Score by Job Type. Specifically, it was predicted that jobs that typically required less complex skills such as those related to w orking in fast food settings would have individuals who were less engaged in their jobs. This hypothesis was tested utilizing a univariate ANOVA and the Bonferroni post-hoc test was used to analyze the relationship of between-group differences to determine if adolescents working at fast food restaurants were less engaged in their jobs than those working in other types of job settings. There was a signific ant effect for job type for work engagement, $F(7,78)=3.75, p=.001$. However, post hoc comparison using the Bonferroni correction indic ated that the mean work engagement score for participants working in fast food $(M=2.50, S D=1.48)$ w as not signific antly different than the other job types (e.g., clerical, physical labor, customer service, retail/sales position, childcare, restaurant work, other). It also important to note that their were no 
other signific ant differences found between groups (e.g., job types). This may due to the low sample size when the sample was divided into 8 groups.

Finally, hypothesis 5 predicted that average hours worked per week would have a curvilinear relationship (inverted U-shaped) with work engagement. This hypothesis was tested utilizing quadratic regression analysis which is a method used to test model curves without having to model a complicated non-linear model. Average number of hours worked per week w as not a significant predictor for work engagement $F(2,84)=1.22, p>.05)$, also displayed on the scatterplot in Figure 4. The quadratic regression model explained a mere $2.8 \%$ of the variance.

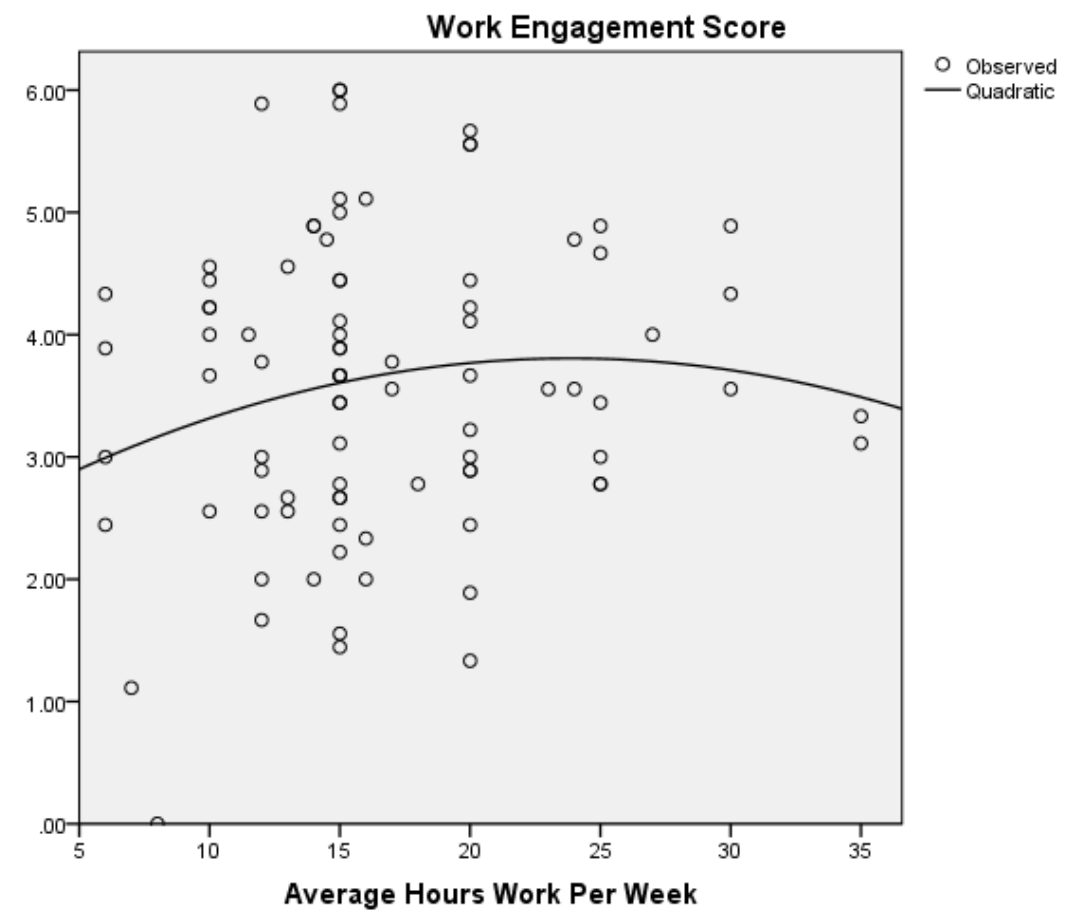

Figure 4. Scatterplot comparing average hours worked per week to work engagement 


\section{CHAPTER V}

\section{DISCUSSION}

The results of the current study provide knowledge regarding what factors may and may not affect w ork engagement in adolescents. This study provided some of the first data directly measuring w ork engagement in adolescents as most of the literature involving adolescent work experiences has focused on quality of work and its relationship to negative behavior and academic outcomes without assessing engagement. This study contributes to a more inclusive understanding of the different work experiences during adolescence as this is an important time prior to adulthood where adolescents begin or continue to develop their voc ational identity. Although work may not take up a majority of the adolescent's time during the week (based on average hours worked per week in this study), longitudinal studies (e.g., Mortimer et al., 1996) have shown that the vocational identity adolescents develop may carry over into adulthood. In observing what may impact how engaged adolescents are at work (and engagement's antecedents and correlates), managers may help create a stronger identity for adolescents to build on as they transition into adulthood. The results of this study may benefit both adolescents and employers by understanding what may keep young employees more engaged and help develop teenage w orkers for the adult w orkplace. Adolescence is an important time for identity formation (Erickson, 1968) and their first foray into the working world may have signific ant impacts on how they initially shape their viewpoints of work. The quality and type of job an adolescent has may also influence how he or she approaches work. As Mortimer et al. (1996) found support for their competence model, it should be noted that we should not overgeneralize this finding. If an 
adolescent has a low skill and/or low quality job, it may lead them to have a more cynical outlook of work in general.

Support for the relationships between certain job characteristics and work engagement were found in the current study. As expected, task significance and task identity were found to be the most (and only) signific ant predictors of work engagement compared to other job characteristic s (autonomy, feedback, and skill variety were found to be non-significant). This observation was further supported by higher engagement scores for adolescents w orking in jobs that have higher levels of these characteristics, such as childcare and customer service, compared to jobs with less significant long-term impact on a person's life (e.g., fast food, retail). Childcare is a highly personal job and their tasks may be viewed as more significant given that workers are caring for another person's child. Adolescent workers in customer service type roles also see the impact they have in helping the customer with their issues. When choosing vocational roles, adolescents may want to focus on jobs where their tasks are important inside and outside of work (task signific ance) and when they can see their work or tasks from beginning to end (task identity). This appears to be related to higher engagement. Support was also found for task identity signific antly predicting w ork engagement, which goes hand-in-hand with task signific ance as a significant correlation was found between task identify and task signific ance (refer to Table 2 for correlations).

Task identity is defined as the degree to which the job requires completion of a "whole" and identifiable piece of work - that is, doing a job from beginning to end with a visible outcome. (Hackman \& Oldman, 1975). When adolescent w orkers are able to see their jobs contributing to a larger purpose and see w ork from start to finish, they tended to be more engaged in their jobs. Jobs in fast food, retail, and clerical work tended to only have the adolescent involved in one part of the w ork that is simple and repetitive. Data from current study showed that participants in the job categories of clerical $(M=21.86)$, retail $(M=23.32)$, and fast food $(M=24.75)$ were among the 
least satisfied with their jobs compared to other job types (restaurant, customer service, childcare, other).

Job satisfaction was significantly correlated with work engagement in adolescents in the current study. An exploratory analysis was also conducted to see if this relationship with work engagement also was observed with coworker and supervisor satisfaction (both were found to be signific antly correlated). Adolescents work for various reasons and the results indic ate that as long as they are satisfied with their job, coworker, and/or supervisor they will be more engaged than those that are less satisfied. How ever, this result should be interpreted with caution. It can be argued that satisfaction does not always mean one is more engaged and contributing to their w ork. The highest job satisfaction w as found in childcare and customer service, two jobs that typic ally require one to be engaged throughout the day. However, it should be noted that job satisfaction and work engagement were found to be signific antly correlated lending support to the argument that work engagement may be a form (or overlap heavily) with job satisfaction (i.e., old wine in a new bottle). An exploratory analysis was conducted to see if there was a strong correlation between task signific ance and task identity with job satisfaction, and a significant correlation was found for both, lending additional support to that job satisfaction and work engagement may have heavy construct overlap.

Contrary to expectations, work-school conflict did not moderate the relationship between school and work engagement. It is important to note that work and school engagement were highly correlated with one another and that may play a role in why there was not a significant moderator effect. Adolescents hold different jobs that require different levels of skill, whereas w ork in fast food or clerical work can be more repetitive and low in skill, while jobs in childcare and customer service require more engagement among those employed. Future research could gather more data on various job categories and examine the potential moderating effect of workschool conflict based on job difficulty or skill requirements. It is also notew orthy that $65 \%$ of the adolescents in this study worked few er than 20 hours per week on average, which is the number 
many research studies have pointed to or used as a cut-off for research focused on work interfering with school. It may be that these similar negative consequences of working more than 20 hours also apply to work engagement in the same manner.

The average hours worked per week was also found to have a non-significant curvilinear relationship (inverted U-shaped) with work engagement. It was predicted that adolescents would be most engaged when they did not work too little or too much (although not tested specifically, this was conceptualized as around the 10 hours per week). The reason this was not supported may be due to job characteristics and job type having a stronger role in work engagement than mere number of hours w orked per week. It also may be that a transformational leader (e.g., supervisor) at work can play a signific ant role in influencing work engagement and/or hours w orked per week. Macy \& Schneider (2008) indicated that transformational leadership can moderate and/or impact state and behavioral engagement. If an adolescent has a transformational leader, he or she may want to work more hours and/or be more engaged. However, more research is needed in examining what the optimum range of hours worked per week is as it relates to work engagement and additional contextual variables (e.g., transformational leadership) in the w orkplace.

Finally, results indicated that work engagement did not significantly differ by job type. In particular, jobs with lower skill (e.g., fast food, clerical) were not signific antly different in terms of work engagement than other job types (e.g., child care, customer service). It is important to note that the sample size for fast food workers and clerical workers were quite low in this study and impacted the strength of this analysis. However, directionally the results indicated that fast food workers and clerical workers exhibited the low est work engagement compared to those in the three most frequent job types (child care, customer service, restaurant workers). A larger sample size is needed to adequately assess this relationship. Also, it may be that this is changing with the recent downturns of the economy dating back to 2008 as more adults are taking on lower wage/skill roles such as fast food. 


\section{Limitations and Future Directions}

There were a number of potential limitations with regard to this study with the most signific ant limitation being that of sample size. Getting adolescent participants to take such a long questionnaire was difficult in building the sample size needed. Future researchers can look to create more fostering relationships with teachers and schools so that class time may be given to complete the questionnaire as opposed to asking students to take outside of school. Secondly, all data was self-reported by the participants. These may be confounded with error and further studies can examine getting this information more objectively or from additional sources (e.g., peers, parents, supervisors). Data was also collected from four different schools: three in the Bloomington-Normal area and one in the Chicago-suburb area which may have impacted results, although all schools were in suburban neighborhoods. One the on hand it may be limiting in having schools geographic ally far apart, on the other hand it may make the sample more diverse.

Future research would benefit from looking at work and school engagement with a longitudinal design, specific ally, to observe how w ork or school engagement changes (or does not change) over time. Macy \& Schneider (2008) reviewed trait, state, and behavioral engagement and a longitudinal design may show support for a specific type of engagement being developed in adolescence. Because trait engagement is viewed as more stable (i.e., personality trait), whereas state engagement is more temporary and may fluctuate more (e.g., mood), it may be the case that trait engagement is only developed as adolescents work for longer periods of time within one job or occupation. A longitudinal study would also be able to measure similarities in job type during adolescence to later adulthood to see if adolescents are more engaged at various points in their w ork experience due to having jobs in fields they aspire to focus on in their later adulthood years (i.e., in same career field).

To date, no studies have been published that directly measure work engagement in adolescents and the limited amount of research in this area allows for future research to build upon the results of this study. The results of the current study are some of the first data to show 
how work and school engagement can be related and the surrounding factors. Most research prior to this has focused on work hours, and work quality (to some degree) as it relates to schoolwork. Adolescence is a time of important identity formation and the first formal introduction to working world for most. It cannot be understated the importance of looking at the relationships and experiences one has at work during these times. 
Table 1

Count \& Percent of Age, Gender, Job Categories, and Average Hours Worked per Week

\begin{tabular}{lll}
\hline Category & $N$ & $\%$ \\
\hline Age & & \\
\hline 1. Age 17 & 92 & $95 \%$ \\
2. Age 16 & 3 & $3 \%$ \\
3. Age 15 & 2 & $2 \%$ \\
\hline Gender & & \\
\hline 1. Female & 64 & $66 \%$ \\
2. Male & 33 & $34 \%$ \\
\hline School & & \\
\hline 1. Neuqua Valley & 60 & $62 \%$ \\
2. Bloomington & 21 & $22 \%$ \\
3. TriValley & 12 & $12 \%$ \\
4. UHigh & 4 & $4 \%$ \\
\hline Job Type & \multicolumn{2}{l}{} \\
\hline 1. Retail/Sales Position & 23 & $24 \%$ \\
2. Restaurant work (not fast food) & 19 & $20 \%$ \\
3. Customer Service & 13 & $13 \%$ \\
4. Physical Labor & 12 & $12 \%$ \\
5. Childcare & 8 & $8 \%$ \\
6. Clerical & 8 & $8 \%$ \\
7. Other & 6 & $6 \%$ \\
8. Fast food & 4 & $4 \%$ \\
9. Did not answer & 4 & $4 \%$ \\
\hline Average Hours Worked per Week & \multicolumn{2}{l}{} \\
\hline 1. Work less than 20 hours per week & 63 & $65 \%$ \\
2. Work 20 hours/week or more & 34 & $35 \%$ \\
\hline & & \\
\hline & &
\end{tabular}


Table 2

Means, Standard Deviations, and Correlations Between Measures

\begin{tabular}{|c|c|c|c|c|c|c|c|c|c|c|}
\hline Variable & $M$ & $S D$ & 1 & 2 & 3 & 4 & 5 & 6 & 7 & 8 \\
\hline 1. Work Engagement (Utrecht) & 3.58 & 1.20 & & & & & & & & \\
\hline 2. School Engagement (Utrecht) & 2.81 & 1.02 & $.423^{* *}$ & & & & & & & \\
\hline 3. Work-School Conflict (WSC) & 2.29 & .81 & -.118 & .052 & & & & & & \\
\hline 4. Job Satisfaction (JDI) & 26.84 & 12.11 & $.643 * *$ & .214 & -.045 & & & & & \\
\hline 5. Skill Variety (JDS) & 2.71 & .87 & $.547 * *$ & .243 & .193 & $.454 * *$ & & & & \\
\hline 6. Task Identity (JDS) & 3.64 & .65 & $.500^{* *}$ & .202 & .118 & $.285^{* *}$ & $.415^{* *}$ & & & \\
\hline 7. Task Significance (JDS) & 3.40 & .76 & $.613^{* *}$ & .392 & $.265^{*}$ & $.358 * *$ & $.600^{* *}$ & .441 & & \\
\hline 8. Feedback (JDS) & 3.61 & .76 & $.509 * *$ & .039 & .122 & $.265^{*}$ & $.524 * *$ & .476 & $.464 * *$ & \\
\hline 9. Autonomy (JDS) & 3.34 & .84 & $.390^{* *}$ & .081 & .064 & $.290 * *$ & $.431 * *$ & .321 & $.253^{*}$ & $.513 * *$ \\
\hline
\end{tabular}

* Correlation is signific ant at the 0.05 level (2-tailed)

** Correlation is significant at the .01 level (2-tailed) 
Table 3

Job Type and Work Engagement Score

\begin{tabular}{|c|c|c|}
\hline Category & $N$ & $\begin{array}{c}\text { Work } \\
\text { Engagement } \\
\text { Score }\end{array}$ \\
\hline 1. Retail/Sales Position & 21 & 3.16 \\
\hline 2. Restaurant work (not fast food) & 18 & 3.54 \\
\hline 3. Customer Service & 12 & 4.39 \\
\hline 4. Physical Labor & 11 & 3.47 \\
\hline 5. Childcare & 7 & 4.67 \\
\hline 6. Clerical & 8 & 3.03 \\
\hline 7. Fast food & 4 & 2.50 \\
\hline 8. Other & 5 & 4.44 \\
\hline
\end{tabular}




\section{REFERENCES}

Barling, J., Rogers, K. A., \& Kelloway, E. K. (1995). Some effects of teenagers' part-time employment: The quantity and quality of work make the difference. Journal of Organizational Behavior, 16, 143-164.

Bass, B. M. (1999). Two decades of research and development in transformational leadership. European Journal of Work and Organizational Psychology, 8, 9-32.

Bluestein, D. L. (1992). Applying current theory and research in career exploration to practice. The Career Development Quarterly, 41, 174-184.

Brogan, D.T. (2010). Stuck in the Middle: Career Progress, Motivation, and Engagement Among Urban Middle School Students. (Doctoral dissertation). Retrieved from ProQuest Dissertations and Theses. (UMI Number: 3397764)

Bronfenbrenner, U. (1979). The ecology of human development. Cambridge, MA; Harvard University Press.

Brown, S. P. (1996). A meta-analysis and review of organizational research on job involvement. Psychological Bulletin, 120, 235-255.

Bureau of Labor Statistics. (2013). Employment status of the civilian non-institutional population by age, sex, and race [Table]. Retrieved from http://www.bls.gov/web/empsit/cpseea13.htm.

Burke. (2005). Employee engagement. Retrieved from www.burke.com/EOS/prac_EmployeeEngagement.htm.

Cohen, J. (1988). Statistical power analysis for the behavioral sciences (2nd ed.). Hillsdale, NJ: Erlbaum.

Erikson, E. E. (1968). Identity: Youth and crisis. New York: Norton.

Erickson, T. J. (2005). Testimony submitted before the U.S. Senate Committee on Health, Education, Labor and Pensions, May 26.

Fleming, J. H., Coffman, C., \& Harter, J. K. (2005). Manage your human sigma. Harvard Business Review, 83, 106-115

Greenberger, E., Steinberg, L. (1986). When teenagers work (Basic Books, New York). 
Grotevant, H. D. (1992). Assigned and chosen identity components: A process perspective on their integration. In G. R. Adams, T. P. Gullotta, \& R. Montemayor (Eds.), Adolescent identity formation: Advances in adolescent development (pp. 73-90). Newbury Park, CA: Sage.

Hackman, J. R., \& Oldham, G. R. (1975). Development of the job diagnostic survey. Journal of Applied Psychology, 60, 159-170.

Hackman, J.R. (1980) Work Redesign and motivation. Professional Psychology, 11, 445-45..

Hamilton, S. (1990). Apprenticeship for adulthood. New York: Free Press.

Harter, J. K., Schmidt, F. L., \& Hayes, T. L. (2002). Business-unit-level relationship between employee satisfaction, employee engagement, and business outcomes: A meta-analysis. Journal of Applied Psychology, 87, 268-279.

Kenny, M. E., Blustein, D. L., Haase, R. F., Jackson, J., \& Perry, J. C. (2006). Setting the stage: Career development and the student engagement process. Journal of Counseling Psychology, 53, 272-279.

Kohn. M.L., \& Schooler, C. (1982). Job conditions and personality: A longitudinal assessment of their reciprocal effects. American Journal of Sociology, 87, 1257-1286.

Lee, J. C, \& Staff, J. (2007). When work matters: The varying impact of adolescent work intensity on high school drop-out. Sociology of Education, 80(2), 158-178.

Levine, K. J., \& Hoffner, C. A. (2006) Adolescents' conceptions of work: What is learned from different sources during anticipatory socialization? Journal of Adolescent Research, 21, 647-669.

Loher, B. T., Noe, R. A., Moeller, N. L., \& Fitzgerald, M. P. (1985). A meta-analysis of the relation of job characteristics to job satisfaction. Journal of Applied Psychology, 70, 280289.

Luyckx, K., Duriez, B., Klimstra, T., \& De Witte, Hans. (2010). Identity statuses in young adult employees: Prospective relations with work engagement and burnout. Journal of Vocational Behavior, 77, 339-349.

Macey, W. H., \& Schneider, B. (2008). The meaning of employee engagement. Industrial and Organizational Psychology: Perspectives on Science and Practice, 1, 3-30.

Markel, K. S., \& Frone, M. R. (1998). Job characteristics, work-school conflict, and school outcomes among adolescents: Testing a structural model. Journal of Applied Psychology, 83, 277-287.

Marsh, H. W., \& Kleitman, S. (2005). Consequences of employment during high school: Character building, subversion of academic goals, or a threshold? American Educational Research Journal, 42, 331-369.

Mihalic, S., Elliott, D. (1997). Short and long term consequences of adolescent work. Youth and Society, 28:464-498. 
Mortimer, J.T. (2003). Working and growing up in America. Cambridge: Harvard University Press.

Mortimer, J. T., Finch, M., Ryu, S., \& Shanahan, M. (1996). The effects of work intensity on adolescent mental health, achievement, and behavioral adjustment: New evidence from a prospective study. Child Development, 67, 1243-1261.

Mortimer, J.T., Pimentel, E., Ryu, S., Nash, K., \& Lee, C. (1996). Part-time work and occupational value formation in adolescence. Social Forces, 74 (4), 1405-1418.

Mortimer, J., Finch, M., Ryu, S., \& Shanahan, M. (1996). The effects of w ork intensity on adolescent mental health, achievement, and behavioral adjustment: New evidence from a prospective study. Child Development, 67:1243-1261.

Mortimer, J. T., Zimmer-Gembeck, M., Holmes, M., \& Shanahan, M. (2002). The process of occupational decision making: Patterns during the transition to adulthood. Journal of Vocational Behavior, 61(3), 439-465.

New man, D., \& Harrison, D. (2008). Been there, bottled that: Are state and behavioral work engagement new and useful construct "wines"? Industrial and Organizational Psychology: Perspectives on Science and Practice, 1, 31-35.

Roznow ski, M. (1989). An examination of the measurement properties of the Job Descriptive Index with experimental items. Journal of Applied Psychology, 74, 805-814.

Schaufeli, W.B., Martinze, I., Marques-Pinto, A., Salanova, M., \& Bakker, A.B. (2002). Burnout and engagement in university students: A cross national study. Journal of Cross-Cultural Psychology, 33, 464-481.

Schaufeli, W. B., \& Bakker, A. B. (2003). Test manual for the Utrecht Work Engagement Scale. Unpublished manuscript, Utrecht University, the Netherlands. Retrieved from http://www.schaufeli.com.

Schaufeli, W. B., Bakker, A., \& Salanova, M. (2006). The measurement of work engagement with a short questionnaire: A cross-national study. Educational and Psychologic al Measurement, 66, 701-716.

Schill, W., McCartin, R., \& Meyer, K. (1985). Youth employment: Its relationship to academic and family variables. Journal of Vocational Behavior 26:155-163.

Schoenhals, M., Tienda, M., \& Schneider, B. (1998). The educational and personal consequences of adolescent employment. Social Forces, 77, 723-748.

Schw artz, S. J., Cote, J. E., \& Arnett, J. J. (2005). Identity and agency in emerging adulthood: Two developmental routes in the individualization process. Youth and Society, 37, 201-229.

Shanahan, M. J., Elder, G. H., Burchinal, M., \& Conger, R. D. (1996). Adolescent paid labor and relationships with parents: Early work-family linkages. Child Development, 67, 21732200 . 
Shanahan, M. J., \& Flaherty, B. P. (2001). Dynamic patterns of time use in adolescence. Child Development, 72, 385-401.

Smith, P. C., Kendall, L. M., \& Hulin, C. L. (1969). The measurement of satisfaction in work and retirement: A strategy for the study of attitudes. Chicago, IL: Rand McNally.

Staff, J., Messersmith, E. E., \& Schulenberg, J. E. (2009). Adolescents and the world of work. In R. Lerner \& L. Steinberg (Eds.), Handbook of adolescent psychology (3rd ed., pp. 270313). New York: John Wiley \& Sons.

Staff, J. \& Schulenberg, J. (2010). Millennials and the World of Work: Experiences in Paid Work During Adolescence. Journal of Business Psychology, 25, 247-255.

Steinberg L. \& Cauffman E. (1995). The impact of employment on adolescent development. Annals of Child Development, 11:131-166.

Stern, D., McMillion, M., Hopkins, C., \& Stone, J.R. III (1990). Work experience for students in high school and college. Youth and Society, 21, 355-389.

Stern, D., \& Nakata, Y. (1989). Characteristics of high school students' paid jobs, and employment experience after graduation. In D. Stern \& D. Eichorn (Eds.), Adolescence and work: influences of social structure, labor markets, and culture (pp. 189-233). Hillsdale, NJ: Law rence Erlbaum.

Stern, D., Stone, J. R., Hopkins, C., \& McMillion, M. (1990). Quality of students’ work experience and orientation tow ard work. Youth \& Society, 22, 263-282.

Stone, J. R., \& Mortimer, J. T. (1998). The effect of adolescent employment on vocational development: Public and educational policy implications. Journal of Vocational Behavior, 53, 184-214.

Strong, N. J., Schneider, K. T., Jarvis, P. A., Heyer, S. A., Conw ay, B. L., Corrigan, J. B.,

Schamell, B. M., \& Pater, L. B. (2008, May). Sexual harassment and coping responses during adolescent work experiences. Paper presented at the American Psychological Society annual conference, Chic ago, IL.

Tow ers-Perrin. (2003). Working today: Understanding what drives employee engagement. Stamford, CT: Author.

Wellins, R., \& Concelman, J. (2005). Personal engagement: Driving growth at the see-level. Retrieved from www.ddiw orld.com/pdf/ddi_personalengagement_ar.pdf

Wirtz, P. W., Charner, I., \& Fraser, B. S. (1988). Employment of adolescents while in high school: Employment intensity, interference with schoolw ork, and normative approval. Journal of Adolescent Research, 3, 97-105.

Zimmer-Gembeck, M. J., \& Mortimer, J. T. (2006). Adolescent work, vocational development, and education. Review of Educational Research, 76, 537-566. 